Research article

\title{
Socio-economic impacts of charcoal production in Oke-Ogun area of Oyo State, Nigeria
}

\author{
Olasimbo Olarinde ${ }^{1}$ and Johnson Adeyinka Olusola ${ }^{2 *}$ \\ ${ }^{1}$ Federal Ministry of Agriculture and Rural Development, Akure Zonal Office, Akure, Nigeria \\ ${ }^{2}$ Department of Forestry and Wood Technology, Federal University of Technology, \\ Akure, Ondo State, Nigeria \\ *Corresponding Author: johnsonolusola5@gmail.com \\ [Accepted: 30 March 2018]

\begin{abstract}
Many households in developing countries experience low energy consumption and this make them depend upon wood fuels for their energy. This study examined socio-economic impacts of charcoal production in Oke-Ogun, Oyo State, Nigeria. Two Local Government Areas were selected based on the accessibility and the availability of charcoal farmers among ten Local Government Areas. Results show that $74 \%$ of the respondents were male while $26 \%$ were female that are into production of charcoal in the study area. $37.5 \%$ of the age range (41-50) of respondent produces more charcoal than other age range. The respondent did not go beyond primary school educationally and they are all married. However, respondents with over 11-20 years of experience in the production of charcoal have higher percentage of frequency. Some of the problem faced by the producers of charcoal in Oke Ogun area are scarcity of trees, wildfire, government disturbance and transportation. Trees commonly used for production are from inherited farms and most of the trees used are Butyrosopermum paradoxium, Dialium guineense, Terminalia glaucencens, Khaya ivorensis. Production is once in a month and later exported. Energy provision is a basic human need and consumption is closely related to the level of a country's development.
\end{abstract}

Keywords: Charcoal - Energy consumption - Fuel - Forest disturbance.

[Cite as: Olarinde O \& Olusola JA (2018) Socio-economic impacts of charcoal production in Oke-Ogun area of Oyo State, Nigeria. Tropical Plant Research 5(1): 46-52]

\section{INTRODUCTION}

Poverty is one of the greatest moral challenges the whole world is facing in which sixth of the world's population living on less than $\$ 1$ a day. Development initiatives to combat this have been implemented through the Millennium Development Goals (MDG) that aim to reduce poverty in half by 2015 (UNDP 2005). Over 90 $\%$ of the 1.2 billion living in poverty worldwide rely on forests to some extent for subsistence needs. Whilst forest resources provide a wide range of benefits to the rural poor, they also contribute significantly to the economies of developed and developing nations (Sengupta \& Maginnis 2005). The extraction of timber for wood fuels accounts for $61 \%$ of total wood removals from forest (FAO 2005). This highlights the importance of these fuels in the energy mix of many countries. Energy provision is a basic human need and consumption is closely related to the level of a country's development (UN-Energy 2005). In many Sub-Saharan Africa, there is low energy consumption among household as well as in many other developing countries and this makes them too heavily dependent upon wood fuels for their energy requirements (Arnold \& Persson 2005). The growing demand for charcoal in these countries has resulted in localized deforestation in vulnerable areas. Household fuels energy play a major role in domestic cooking, space heating and lighting, but, ESMAP (2003), excludes fuels for transportation. Many of the different types of households 'fuels in use in developing countries come under the category of "traditional", which include animal dung and agricultural residues, as well as wood fuel. Wood fuel, in the view of World Resources (2001), comprises of charcoal, firewood and other wood-derived fuels; and also constitutes the most important form of non-fossil energy used in households. 
In Nigeria as a whole, charcoal is not only the major source of household energy for the majority of the rural and urban dwellers, it is also a significant contributor to national energy balances, an important source of household incomes, and a potentially renewable energy source capable of powering significant economic growth while reducing dependency of poor developing countries on costly energy imports (Arnold et al. 2006, Sepp 2010). Several advantages make charcoal attractive for cooking and heating, especially among the urban poor. Compared to firewood, charcoal has higher energy content, is less bulky, easier to transport, and more accessible, and burns more cleanly (with less smoke) (MARGE 2009, Akpalu et al. 2011). The problem of fuel in Nigeria is gradually becoming unbearable, thus, this gave room for constant deforestation to meet domestic needs. Most of the household in most of our communities now depend on charcoal because of its refined nature when compared with firewood. Therefore, as a result, more and more household shifted their demand for this because kerosene and gas are beyond the reach of household in the study area. There are numerous attempts to reduce this by promoting more efficient technique of charcoal making, some people have gone as far as to advocate the active discouragement of charcoal making or even it outright banning (Gerald 1986). Yet in another area, the effort can be made for expanding charcoal production as a means of utilizing waste wood and creating an opportunity for local employment and economic development.

Commercial fuelwood extraction such as charcoal production requires a large volume of wood, which in turn depletes tree stocks causing deforestation. Thus, little is known about the actual extent of deforestation due to urban charcoal use. Neither are the social and economic patterns, which determine the charcoal exploitation, or the policy options available to mitigate the problem. This has implications for the country regarding its ability to design and implement appropriate energy policies that can intervene in the charcoal sectors. Therefore, this research article focused on charcoal production, its impact on the people living in the Oke-Ogun area of Oyo State, Nigeria. Also, it also examined some problems associated with the energy sourcing by household involving in the charcoal production.

\section{METHODOLOGY}

Study Area

The study was carried out in Oyo State, and the State is an inland State among the States in Southwestern Nigeria. It covers a total area of $28,454 \mathrm{~km}^{2}$ and has a population of $5,591,589$ by the 2006 population census (NPC 2006). Oyo State is bounded in the north by Kwara State, in the East by Osun State, in the south by Ogun State and in the west partly by Republic of Benin and partly by Ogun State, (Handbook on Agricultural Activities in Oyo State 2001). The State lies between latitudes $7^{\circ} 3^{1}$ and $9^{\circ} 2^{1}$ north of the equator and longitudes $2^{\circ} 47^{1}$ and $4^{\circ} 23^{1}$ east of the meridian. Due to this location, the State has both wet and dry seasons. The wet season is the period of rainfall, which is between April and October which is characterized by double maxima distribution in the Southern part, as a result of the influence of the southwestern monsoon wind on the atmosphere. The dry season covers between November and March and it is characterized by hot weather. The weather in Oyo State is dry and it's accompanied by dust storms due to the effect of North-East trade winds between the months of December till early January (Handbook on Agricultural Activities in Oyo State 2001).

\section{Research Method}

A structured questionnaire was developed and used to collect information from villagers (those Involved in the charcoal production in Oke-Ogun area of Oyo State) in other to determine the socioeconomic importance of charcoal production in the study areas. The questionnaire was used to collect information on the data on socioeconomic characteristics such age of the respondents, marital status of charcoal producers, family size, education background, production experience and gender of the respondents etc. The questionnaire was pretested before final administration to respondents. Descriptive statistics such as Bar chart, Frequency Distribution, Tables and Percentages were used for the interpretation of results.

\section{RESULTS AND DISCUSSION}

Socio-economic Characteristics of the Respondents

The results of the socioeconomic characteristic of charcoal producers in Oke-Ogun Area were presented in table 1 below. Some of the characteristics discussed here are gender, marital status, age, educational level, primary occupation, household size, charcoal production experience. Firstly, there is a distinction between male and female and the type of work they can do. Males are known for jobs that are energy demanding unlike females. Therefore, from the result of table 1, it was observed that about $74 \%$ of the respondents are male while www.tropicalplantresearch.com 
less than $30 \%$ are female that are involving in the production of charcoal in Oke-Ogun area of Oyo State which was in line with the report of (Ogara 2011). Also, considering the age range of the people carrying out the charcoal production, it was discovered that people that are between the age range of 41 to 50 years has the highest percentage of 37.5 which implies that they are more involved in the production of charcoal than those that are of other age ranges in Oke-Ogun area of Oyo State and the next set of people are those that are between the age range of 51 to 60 years which have the record of $23.8 \%$ followed by those that are less than 30 years of age with the percentage of 11.3 and the least age range involved are the people above 60 years of age having a percentage of 6.9. This is similar to practices in other parts of the world most especially as reported in Asia by (Bhattarai 1998) that most of the people that involved in charcoal production in Asia are those that are in active age range of 50-60 years of age.

Table 1. Socio-economic characteristics of the respondents.

\begin{tabular}{|c|c|c|}
\hline Variable & Frequency & Percentages \\
\hline \multicolumn{3}{|l|}{ Gender } \\
\hline Male & 118 & 74.0 \\
\hline Female & 42 & 26.0 \\
\hline Total & 160 & 100.00 \\
\hline \multicolumn{3}{|l|}{ Age } \\
\hline$<30$ & 18 & 11.3 \\
\hline $31-40$ & 33 & 20.6 \\
\hline $41-50$ & 60 & 37.5 \\
\hline $51-60$ & 38 & 23.8 \\
\hline$>60$ & 11 & 6.9 \\
\hline Total & 160 & 100.00 \\
\hline \multicolumn{3}{|l|}{ Educational Status } \\
\hline No formal education & 24 & 15.0 \\
\hline Primary education & 69 & 43.0 \\
\hline Secondary & 51 & 32.0 \\
\hline Higher education & 16 & 10.0 \\
\hline Total & 160 & 100.00 \\
\hline \multicolumn{3}{|l|}{ Marital Status } \\
\hline Married & 133 & 83.0 \\
\hline Single & 11 & 7.0 \\
\hline Widower & 8 & 5.0 \\
\hline Widow & 6 & 4.0 \\
\hline Divorce & 2 & 1.0 \\
\hline Total & 160 & 100.00 \\
\hline \multicolumn{3}{|l|}{ Primary occupation } \\
\hline Farming & 119 & 74.4 \\
\hline Artisans & 29 & 18.1 \\
\hline Unemployed & 12 & 7.5 \\
\hline Total & 160 & 100.00 \\
\hline \multicolumn{3}{|l|}{ Household Size } \\
\hline$<5$ & 56 & 35.00 \\
\hline $5-10$ & 93 & 58.13 \\
\hline$>10$ & 11 & 6.88 \\
\hline Total & 160 & 100.00 \\
\hline \multicolumn{3}{|l|}{ Experience(years) } \\
\hline$<10$ & 25 & 15.63 \\
\hline $11-20$ & 61 & 38.13 \\
\hline $21-30$ & 39 & 24.4 \\
\hline $31-40$ & 19 & 12 \\
\hline $41-50$ & 16 & 10 \\
\hline Total & 160 & 100.00 \\
\hline
\end{tabular}

The educational status of the people having the charcoal production was also taken into consideration in this study, where it was observed that the highest percentage of the people has a primary school education; about $43 \%$ of them, followed by those with secondary school education, having a percentage $32 \%$ and those that have no formal education with the percentage of 15 while the least percentage (10\%) was found among those that 
have higher education. This was similar to the report of (Ogara 2011) who reported that the trade is mostly involving people with no education, from his report he affirmed that junior class dropouts had the highest number of frequency in his research. To proceed in this study for more information on the production of charcoal, the marital status of the people involved was also noted. It was therefore observed that the percentage of the married people involved is very much higher than the other group of people involving in the production as it carries about $83.0 \%$, the percentage of another group of people involved are very minimal; the singles involved are about 7\%, the widowers are about 5\% while the widows and divorce are about $4 \%$ and $1 \%$ respectively. It is therefore expedient to know if these groups of people have another source of income or primary occupation aside the production of charcoal. It was discovered that about $74.4 \%$ of these people are into farming while about $18.1 \%$ are artisans and the least group of people are unemployed which has the percentage of 7.5\%, which was contrary to finding of (Izekor \& Amiandamhen 2017) who reported that most of the respondents in their study area were business men and women representingaround $52.5 \%$ while others were farmers, artisans, students, civil servants and unemployed respectively. The household size of the respondent was also considered. However, their year of experience in the production of charcoal differs. About $38.13 \%$ of the respondents have been into the production of charcoal for about 11 to 20 years and $24.4 \%$ of them have an experience of about 21 to 30 years. Some of the respondents also, have an experience of fewer than 10 years and they are about $15.63 \%$ while about $12 \%$ of them have an experience of 31 to 40 years and those that have the least experience are about $10 \%$ with the experience of 41 to 50 years.

\section{The Challenges Faced During Charcoal Production}

This research work also looked into some of the challenges faced with the production of charcoal, and it was discovered that charcoal producers in the study area faced numerous problems as revealed from the respondents (Table 2) below. It was showed that about $90 \%$ of the respondents said that trees for charcoal production are getting scarce, unlike two to three decades ago when trees for charcoal production could be gotten a little distance from their villages, but as at time of this research work, they have to go a very long distance in search of the available forest where the kind of wood required could be found (Anderson 1996). This, therefore, results into a change in price in terms of the amount paid by the traders i.e. the farther the distance of production site from the villages, the higher the transportation cost and the lesser the price that traders would want to pay (Izekor \& Amiandamhen 2017). It was also discovered that wildfire as revealed by the respondents is also another problem people were faced with the production of charcoal which is negatively affects both the charcoal producers and nonproducers and even lead to total destruction of the forest where the production is being carried out. About $70 \%$ of the respondents gave this report and that the rate of wildfire in the study area is very alarming. Government also, was said to be a problem unto them in that the Forestry Department of the State usually give them problem by stopping them from exploiting the forest and about $74 \%$ of the respondent fell into this category saying, "forest is what God has blessed them with and nobody can dictate to them when and how to exploit" but it's quite unfortunate that they don't know the gravity of the problem that the forest exploitation can pose on human health. However, the respondents also complained of the difficulty they usually face to get their products transported to where it could be demanded for or purchased and if the products are sold at the production site, it often times result in little or no gain which makes it difficult for them to go into production again as reported by about $74 \%$ of the respondents.

Table 2. Production and challenges faced by the respondents.

\begin{tabular}{lll}
\hline Problems & Support $(\boldsymbol{\%})$ & Indifference $(\boldsymbol{\%})$ \\
\hline Scarcity of Tree & 90 & 10 \\
Wildfire & 69 & 31 \\
Government disturbance & 74 & 26 \\
Transportation & 80 & 20 \\
\hline
\end{tabular}

Resources for charcoal production, production process and other important variables

This study reveals that about $60 \%$ of the respondents source for the wood they use in producing the charcoal from an inherited farmland, while $30 \%$ of them often purchase wood for the purpose of the production and the remaining $10 \%$ of the respondents combines the two sources for their charcoal production (i.e. the source from an inherited farmland and as well as purchasing the wood resource) as represented in table 3. But the case was different from the report of the research conducted by (Izekor \& Amiandamhen 2017) and reported that about 
$51 \%$ of the respondents get their supply of fuel wood from fuelwood sellers $15 \%$ collects theirs from bushes around and $25 \%$ received theirs from farm lands.

Table 3. Resources for charcoal production, production process and other important variables.

\begin{tabular}{|c|c|c|}
\hline Variable & Frequency & Percentages \\
\hline \multicolumn{3}{|l|}{ Wood source } \\
\hline Purchased & 48 & 30.0 \\
\hline Inherited & 89 & 56.0 \\
\hline Purchased and inherited & 23 & 14.0 \\
\hline \multicolumn{3}{|l|}{ Type of forest } \\
\hline Natural & & 80.0 \\
\hline Plantation & & 20.0 \\
\hline \multicolumn{3}{|l|}{ Number of laborers } \\
\hline 0 & 48 & 30.0 \\
\hline 1 & 37 & 23.0 \\
\hline 2 & 22 & 14.0 \\
\hline 3 & 20 & 13.0 \\
\hline 4 & 26 & 16.0 \\
\hline 5 & 2 & 1.0 \\
\hline 6 & 5 & 3.0 \\
\hline \multicolumn{3}{|l|}{ Tree species preferred } \\
\hline Butyrosopermum paradoxium (Emi) & & 50.0 \\
\hline Dialium guineense (Ayin) & & 20.0 \\
\hline Terminalia glaucencens (Idi) & & 6.0 \\
\hline Disternonanthus benthamianus (Ayan) & & 10.0 \\
\hline Khaya ivorensis (Mahogany) & & 4.0 \\
\hline Azadirachta indica (Dongoyaro) & & 2.0 \\
\hline \multicolumn{3}{|l|}{ Number of days } \\
\hline $7-8$ & 37 & 23 \\
\hline $9-15$ & 123 & 77 \\
\hline \multicolumn{3}{|l|}{ Quantity of logs } \\
\hline $1-500$ & 3 & 19.0 \\
\hline $501-1000$ & 40 & 25.0 \\
\hline $1001-1500$ & 27 & 17.0 \\
\hline $1501-2000$ & 38 & 23.0 \\
\hline $2001-2500$ & 22 & 14.0 \\
\hline $2501-3000$ & 22 & 14.0 \\
\hline $3001-3500$ & 5 & 3.0 \\
\hline$>3500$ & 3 & 2.0 \\
\hline \multicolumn{3}{|l|}{ Production/Month } \\
\hline Once & 118 & 74.0 \\
\hline Twice & 34 & 21.0 \\
\hline Three times & 8 & 5.0 \\
\hline \multicolumn{3}{|l|}{ Buyers preferred } \\
\hline Local traders & 53 & 52.0 \\
\hline Exporters & 77 & 48.0 \\
\hline Consumers & - & - \\
\hline
\end{tabular}

Moreover, the source of wood for charcoal production in respect to the type of forest as represented also in Table 3 is also considered in this research and it was discovered that the majority $(80 \%)$ of the respondents gets the wood for charcoal production from the natural forest, while about $20 \%$ of the respondents get their wood from forest reserves. This may be due to the fact that natural habitat environments constitute different species of the tree species, and this can be a factor whereby they prefer going to the natural environment for collecting the tree species used for the charcoal production (Izekor \& Osayimwen 2010). The labour distribution of the respondents in the study area was also put into consideration and it was discovered that $30 \%$ of the respondent used family labour in carrying out their charcoal production as they did not rely on hire labourers at all, While $23 \%$ of the respondents hire just one labourer who happened to be the saw operator that helped the farmers to cut the trees to various sizes. Some of the respondents were discovered as represented in table 3 to be using more than one labourer in their production. About $14 \%, 13 \%$ and $16 \%$ of the respondents have additional 
labourers of $2,3,4$ respectively to themselves in the production but very few of the respondents $(1 \%, 3 \%)$ use additional labourers of 5 and 6 respectively.

Tree species are very much important in the production of charcoal as there are specific trees species that are known to favour charcoal production due to dense and hard charcoal they produce, with higher calorific value (Izekor \& Modugu 2011). These tree species which contain both scientific names and common names are; Butyrosopermum paradoxium (Emi), Dialium guineense (Ayin), Terminalia glaucencens (Idi), Disternonanthus benthamianus (Ayan), Azadirachta indica (Dongoyaro) and Khaya grandofoliola or Ivorensis (Mahogany). It was revealed in table 3 that Butyrosopermum paradoxium accounted for more than 50\% proportion of tree species preferred for charcoal production, Dialium guineense accounted for a proportion of more than $20 \%$ while Disternonanthus benthamianus was revealed to have accounted for $10 \%$ of the proportion of tree preferred for charcoal production. Terminalia glaucencens, Khaya species and Azadirachta indica (Dongoyaro) accounted for the proportion of $6 \%, 4 \%$ and $2 \%$ respectively. It was said that mahogany was very common in the study area but due to continuous exploitation it is gradually going into extinction. According to the respondents, presently in the study area, all these trees are not as common as before. However, the method of charcoal production has a great impact on the output or the yield of the production. The major production method practice in the study area is traditional methods which is a mound, and are usually rectangular and circular in shape. Charcoal is produced in mound igniting the kiln and allows carbonization under limited air supply. It was revealed in table 3 that less than $30 \%$ of the respondents accounted for those of which their carbonization lusted for 7-8 days while more than $70 \%$ accounted for those their carbonization lasted for 10-15 days. Carbonization is subject to the level of dryness of the wood and the quantity of wood used for charcoal production.

\section{CONCLUSION}

The study established that charcoal production was profitable in the study area. Though production was carried out mainly during off seasons, when rainfall was minimal or not available. This period (off season) income of the farmers is at a low state and in most cases none at all. The farmers now found solace in charcoal productions, which now stands as another source of revenue for the farmers in the study area. But the extent of deforestation and ozone layer depletion in the study area is alarming. Massive afforestation should be encouraged in the study area to lessen the effect of deforestation and fire outbreak caused through this practice should be managed.

\section{ACKNOWLEDGEMENTS}

We wish to appreciate the farmers in the study areas for giving us audience and information's on charcoal production in Oke-Ogun area of Oyo State.

\section{REFERENCES}

Akpalu W, Dasmani I \& Aglobitse PB (2011) Demand for cooking fuels in a developing country: to what extent do taste and preferences matter? Energy Policy 39: 6525-6531.

Anderson D (1996) Energy and the Environment: Technical and Economic Possibilities, Finance and Developments, Appraisal. Available from: http://www.worldbank.org/wbi/sourcebook/sba104.htm. (accessed: 30 Jul. 2007).

Arnold JEM, Köhlin G \& Persson R (2006) Wood fuels, livelihoods, and policy interventions: changing perspectives. World Development 34(3): 596-611.

Arnold MJE \& Person R (2005) Reassessing the fuel wood situation in developing countries. In: Sayer J (ed) The Earthscan Reader in Forestry and Development. London, Earthscan, pp. 206-214.

Bhattarai TN (1998) Charcoal and its socio-economic importance in Asia. Paper presented at the regional training at the regional training on Charcoal production, Pontianak, Indonesia, organized by RWEDP, $12 \mathrm{p}$.

ESMAP (2003) Household fuel use and fuel switching in Guatemala. Joint UNDP/world Bank Energy Sector Management Assistance Project FAO, Rome No 42, 125 p.

FAO (2005) Global Forest Resources Assessment 2005. FAO Forestry Paper 147: Progress towards sustainable forest management. Available from: ftp://ftp.fao.org/docrep/fao/008/A0400E/A0400E00.pdf. (accessed: 04 Jan. 2008)

Gerald F (1986) Charcoal Making in Developing Countries Technical Report No 5, Goals, pp 37-41. Available 
from: http://esa.un.org/un-energy/pdf/UN-ENRG\%20paper.pdf. (accessed: 14 Jul. 2006)

Handbook on Agricultural Activities in Oyo State (2001) A Book Prepared household energy source in Benin City. African Scientist 2(1): 33-39.

Izekor DN \& Amiandamhen SO (2017) Utilization of Fuelwood as Household Energy among Residents of Benin Metropolis, Edo State, Nigeria. Nigerian Journal of Agriculture, Food and Environment 13(2): 174178.

Izekor DN \& Modugu WW (2011) Utilization of sawmill wood waste in forest resource conservation. In: Proceeding of the $34^{\text {th }}$ Annual conference of the Forestry Association of Nigeria held at Oshogbo, Osun State, Nigeria, pp 418-426.

Izekor DN \& Osayimwen FE (2010) Potentials of sawmill wood wastes utilization as household energy source in Benin City. African Scientist 2(1): 33-39.

MARGE (Marchéage et Gestion de l'Environnement) (2009) Malawi biomass energy strategy. Consultancy study for Government of Malawi and European Union Partnership Dialogue Facility. Lilongwe: MARGE.

NPC (2006) National Population Commission, Population Census in By the Department of Planning, Research and Statistics of the Development, Secretariat, Ibadan, pp. 1-10.

Ogara JI (2011) Preliminary studies on charcoal production and producers' knowledge of environmental hazards in Nasarawa State, Nigeria. Production Agriculture and Technology 7(2): 68-75.

Sengupta S \& Maginnis S (2005) Forests and development: Where do we stand? In: Sayer J (ed) The Earthscan Reader in Forestry and Development. London, Eathscan, pp. 206-214.

Sepp S (2010) Wood energy: renewable, profitable andmodern. Postfach, GTZ, Germany (DeutscheGesellschaftfürTechnischeZusammenarbeit). Available from: http://www.gtz.de/de/dokumente/ Gtz 2010-en-wood-energy-talking-points.pdf (accessed: 19 Dec. 2011).

UNDP (2005) Basing National Development on the Millennium Development Goals. Available from: http://www.undp.org.mk/Default.asp? where=focusarea\&project=89 (accessed: 18 Apr. 2007).

UN-Energy (2005) The Energy Challenge for Achieving the Millennium Development Goals. Available from: http://www.undp.org/content/undp/en/home/librarypage/environment-energy/sustainable_energy/the_ energy_challengeforachievingthemillenniumdevelopmentgoals.html (accessed: 18 Apr. 2007).

World Resources (2001) People and Ecosystem: The Fraying Web of Life. WRI, Washington D.C. 